\title{
Sürdürülebilir Bir Yöntem / Betonda Puzolan Kullanımı
}

\author{
Uğur Özcan ${ }^{1 *}$, Sena Güngör ${ }^{2}$ \\ ${ }^{\mathbf{1}}$ Fatih Sultan Mehmet Üniversitesi, Mimarlık Fakültesi, Mimarlık Bölümü, İstanbul, Türkiye (ORCID: 0000-0003-0002-4478) \\ 2 Fatih Sultan Mehmet Üniversitesi, Fen Bilimleri Enstitüsü, Mimarlık Anabilimdalı, İstanbul, Türkiye (ORCID: 0000-0002-1124-2385)
}

(İlk Geliş Tarihi 24 Ocak 2019 ve Kabul Tarihi 2 Mart 2019)

(DOI: 10.31590/ejosat.517346)

ATIF/REFERENCE: Özcan, U. \& Güngör, S. (2019). Sürdürülebilir Bir Yöntem/Betonda Puzolan Kullanımı. Avrupa Bilim ve Teknoloji Dergisi, (15), 176-182.

\section{$\ddot{O} \mathbf{z}$}

Günümüzde sürdürülebilir tasarıma ve çevre dostu malzemelerin üretimine yönelik çeşitli çalışmalar yapılmaktadır. Çimento endüstrisi de bu konuya destek olucu yönde çalışmaları kendi alanında yapmaktadır. Çimento üretimi sırasında açığa çıkan karbondioksit $\left(\mathrm{CO}_{2}\right)$ ve sera etkisi yapıcı gazlar çevreye salınmaktadır. Bu nedenle, çimento gibi doğaya zarar veren malzemelere alternatif olabilecek malzemeler aranmaktadır. Günümüzde geopolimer, çevre dostu, ekonomik ve yenilikçi bir ürün olarak yapı teknolojisinde yerini almaktadır. 1978 yılında Fransız malzeme bilimci Joseph Davidovits tarafindan inorganik moleküllerin oluşturduğu yapılara geopolimer adı verilmiştir. Geopolimerler, uçucu küller, yüksek firın cürufları ve silis dumanı gibi termik santrallerin atık malzemelerinden oluşmaktadır. Uçucu kül, kömür ve linyit kullanarak demir, çelik ve diğer metallerin üretimini yapan termik santrallerde atık veya yan ürün olarak ortaya çıkmaktadır. Uçucu küllerin, çimento üretiminde, zemin iyileştirme malzemesi ve inşaat yapı malzemesi olarak kullanılması ile uçucu küllerin oluşumu ve depolanması sonucu meydana gelen çevre problemleri ve doğaya verilen zarar azaltılabilir.

Anahtar Kelimeler: Puzolan, uçucu kül, beton, yapı malzemesi, sürdürülebilirlik

\section{A Sustainable Method / The Use Of Pozzolan In Concrete}

\begin{abstract}
Nowadays, a variety of researches are being conducted on sustainable design and manufacturing of eco-friendly materials. The cement industry is also doing supportive works on this issue in its own field. The production of cement releases carbon dioxide $\left(\mathrm{CO}_{2}\right)$ and greenhouse gas emissions. For this reason, materials which may be an alternative to harmful materials such as cement are sought. Today, geopolymer has become an important topic for building technology as an eco-friendly, economic and innovative product. The structures formed by inorganic molecules by the French materialist Joseph Davidovits in 1978 were called geopolymer. Geopolymer is made from waste materials of thermal power station such as fly ash, silica dume and ground granulated blast furnace slag. Fly ash is waste or by-product obtained from thermal power plants which produce iron, steel and other metals by using coal and lignite. By using fly ash as construction material, ground improvement material and in cement production, it is possible to reduce the environmental problems and natural harm caused by formation and storage of fly ash.
\end{abstract}

Keywords: Pozzolan, fly ash, concrete, construction material, sustainability

*S Sorumlu Yazar: Fatih Sultan Mehmet Üniversitesi, Mimarlık Fakültesi, Mimarlık Bölümü, İstanbul, Türkiye (ORCID: 0000-0003-0002-4478), uozcan@ @sm.edu.tr 


\section{Giriş}

2015 yılında dünyada portland çimento üretimi yaklaşık 4 milyar ton, Türkiye'de ise 75 milyon ton düzeyinde gerçekleşmiştir. Bir ton portland çimentonun üretiminde 0,8 ton karbondioksit $\left(\mathrm{CO}_{2}\right)$ emisyonu oluşmaktadır. Türkiye'de 75 milyon ton portland çimentosunun üretimi sırasında yılda ortalama 60 milyon ton karbondioksit $\left(\mathrm{CO}_{2}\right)$ gazı atmosfere salınmaktadır. Yüksek oranda karbondioksit $\left(\mathrm{CO}_{2}\right)$ ve sera gazlarının atmosfere salınımını azaltmak ve doğaya verilen zararı önlemek amaciyla puzolan bağlayıcıların (geopolimerler), portland çimentosuna alternatif bir malzeme olabileceği düşünülmektedir. Tablo 1'de yıllara göre ülkelerin çimento üretimi gösterilmektedir.

Tablo 1. Y1llara göre ülkelerin çimento üretimi [1]

\begin{tabular}{|l|c|c|c|c|c|c|c|c|}
\hline \multicolumn{8}{|c|}{ Cimento Üretimi (Milyon ton) } \\
\hline$\ddot{\text { Ullke }}$ & $\mathbf{2 0 1 0}$ & $\mathbf{2 0 1 1}$ & $\mathbf{2 0 1 2}$ & $\mathbf{2 0 1 3}$ & $\mathbf{2 0 1 4}$ & $\mathbf{2 0 1 5}$ & $\mathbf{2 0 1 6}$ & $\mathbf{2 0 1 7}$ \\
\hline Çin & 1880 & 2100 & 2210 & 2420 & 2480 & 2350 & 2400 & 2400 \\
\hline Hindistan & 210 & 240 & 270 & 280 & 260 & 300 & 280 & 270 \\
\hline ABD & 67 & 69 & 75 & 77 & 83 & 84 & 85 & 89 \\
\hline Türkiye & 63 & 63 & 64 & 71 & 75 & 71 & 75 & 77 \\
\hline Sundi Arabistan & 42 & 48 & 50 & 57 & 55 & 62 & 62 & 63 \\
\hline Güney Kore & 47 & 48 & 48 & 47 & 63 & 52 & 57 & 59 \\
\hline Rusya & 50 & 56 & 61 & 66 & 68 & 62 & 56 & 58 \\
\hline Brezilya & 59 & 64 & 69 & 70 & 72 & 65 & 57 & 54 \\
\hline Japonya & 51 & 51 & 51 & 57 & 53 & 55 & 53 & 53 \\
\hline
\end{tabular}

Kendi kendine bağlayıcılığı az miktarda yada hiç bulunmayan, buna karşılık su içinde, oda sıcaklığında kireç ile birlikte kimyasal reaksiyona girerek bağlayıcı özelliğe sahip ürünler oluşturan, toz halindeki alüminli ve silisli veya sadece silisli maddelere puzolan adı verilmektedir. Puzolanlar, doğal olan puzolanlar ve yapay olan puzolanlar olarak kendi içerisinde iki ana gruba ayrılmaktadır [2]. En yaygın ve yapay olan puzolan malzeme, termik santrallerden elde edilen uçucu küllerdir.

Uçucu küller, yaklaşık 2300 yıl önce, bilinen en eski hidrolik çimentoların üretiminde kullanılan volkanik küller ile çok benzerdir. $\mathrm{Bu}$ çimentolar küçük bir İtalyan şehri olan Pozzuoli'nin yakınlarında yapılıış ve daha sonra "puzolan" olarak adlandırılmıştır. Uçucu kül, dünyadaki en yaygın ve en çok kullanılan puzolanlardan biridir. Kömür bazlı termik santrallerin atık ürünü olan uçucu küllerin, toprak kirliliği, hava kirliliği, yüzey ve yeraltı su kirliliği, tarımsal arazi ve insan sağlığı üzerinde zararlı etkileri olduğu bilinmektedir [3].

Uçucu küller, camsı, küresel tanecik yapılı parçacıklardan oluşan ve beton içerisinde mineral esaslı bir katkı maddesi olarak kullanılan yapay puzolandır. Kendileri bağlayıcı özellik taşımadıkları halde, sönmüş kireç ile birlikte hidratasyon reaksiyonu oluşturarak su içerisinde sertleşme özelliği gösterirler. Uçucu küller elektrik üretiminde kullanılan termik santrallerden sağlanırlar. Endüstride kullanılamayan kalori değeri az kömürün ince taneli ögütülerek termik santralde yakılması ile oluşan uçucu küller, santral bacası üzerinde bulunan elektro filtreler ve siklon toz toplayıcılarda, elektrostatik ve mekanik yöntemlerle yakalanarak biriktirilirler [4].

Uçucu kül, gri veya koyu gri renge sahip, oldukça küçük tanecikli yapıya sahip olan bir tür malzemedir. Gri rengin koyuluğu veya açıklığı, yakılarak oluşturulduğu kömüre ve bu kömürün yanış şekline bağlıdır. Yanmanın tam olarak tamamlanmadığı durumlarda meydana gelen uçucu kül, içerisinde barındırdığı yanmamış karbon sebebi ile daha koyu siyah renge sahiptir, fakat yanmanın tam olduğu durumlarda açığa çıkan uçucu kül açık renkte olmaktadır [5]. Resim 1'de ASTM-C 618'e göre F ve C tipi uçucu küller gösterilmektedir.

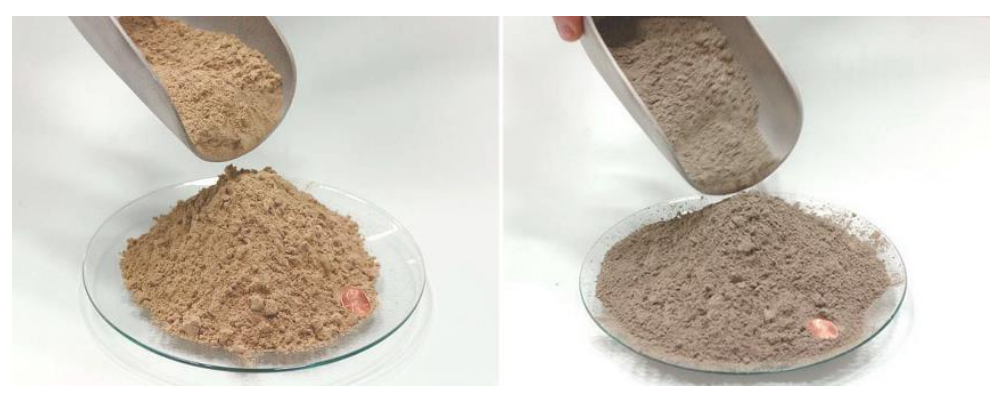

Resim 1. ASTM-C 618'e göre F ve C tipi uçucu küller [6]

Uçucu külün ne düzeyde ince olacağı ilk olarak yakılmak üzere santrale verilen kömürün öğütülerek inceltilme düzeyine bağlıdır. İkinci faktör ise küllerin bacadan atılmasına engel olabilmek ve tutulabilmesidir. Bacadan atılan miktar azaltılabildikçe elde edilen uçucu külün inceliği arttırılabilinecektir. Havaya salınan kül miktarının azaltılması sonucunda çevre kirliliği ve doğaya verilen zararın önüne geçilmesi bir yönüyle sağlanabilinecektir. 
Uçucu külün yoğunluk düzeyi, tanelerin inceliğine ve külün taşıdığı mineralojik yapıya bağlıdır. Uçucu küllerin incelikleri arttıkça yoğunlukları artmaktadır. İçi dolu küresel yapıya sahip taneciklerden meydana gelen uçucu küllerin yoğunluğu $2.2-2.7$ $\mathrm{gr} / \mathrm{cm}^{3}$ arasında değişiklik göstermektedir [5]. Uçucu külün kimyasal yapısında bulunan başlıca bileşenler, $\left(\mathrm{SiO}_{2}\right)$ silikon dioksit, $\left(\mathrm{Al}_{2} \mathrm{O}_{3}\right)$ alüminyum oksit, $\left(\mathrm{Fe}_{2} \mathrm{O}_{3}\right)$ demir III oksit ve $(\mathrm{CaO})$ kalsiyum oksittir. Resim 2'de mikroskop altında uçucu külün görünümü gösterilmektedir.

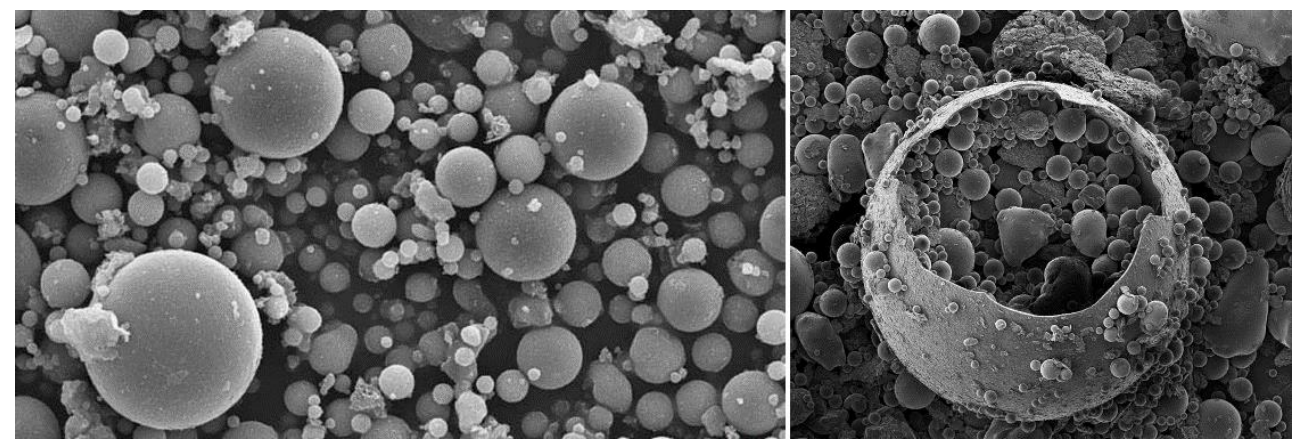

Resim 2. Mikroskop altında uçucu külün görünümü [7]

Uçucu küllerin sınıflandırılması, içerisinde barındırdığı bileşenlerin bileşim oranlarına bağlı olarak yapılmaktadır. Sınıflandırmada ASTM-C 618 ve TS EN 197-1 standartları referans alındığında; ASTM-C 618'e göre uçucu küller F ve C, TS EN 197-1'e bakıldığında ise V (silissi) ve W (kalkersi) olmak üzere ana kategorilere ayrılmaktadır. ASTM-C 618'in F tipi olarak sınıflandırdığı uçucu kül genellikle taş kömüründen elde edilen, puzolanik özelliğe sahip küllerdir. Kalsiyum oksit (CaO) \% 10 'dan az ve $\mathrm{SiO}_{2}, \mathrm{Al}_{2} \mathrm{O}_{3}, \mathrm{Fe}_{2} \mathrm{O}_{3}$ bileşenlerinin toplam oranı \%70'den fazla olan uçucu küller bu kategoride yer almaktadır. $\mathrm{F}$ tipi küller düşük kireç oranına sahip olduklarından beton bileşiminde dayanım oranını artırırlar. ASTM-C 618'e göre C tipi olarak sınıflandırılan uçucu kül ise genellikle linyit kömüründen elde edilir. $\mathrm{Bu}$ küller ise kalsiyum oksit $(\mathrm{CaO})$ oranı \%10'un üstünde ve $\mathrm{SiO}_{2}, \mathrm{Al}_{2} \mathrm{O}_{3}, \mathrm{Fe}_{2} \mathrm{O}_{3}$ bileşenlerinin toplam oranı \%50'den fazla olan, $\mathrm{CaO}$ miktarının fazla olmasından dolayı bağlayıcı özelliklere sahip olan uçucu küllerdir [8].

TS EN 197-1'in V olarak sinıflandırdığı uçucu kül esas olarak $\mathrm{SiO}_{2}, \mathrm{Al}_{2} \mathrm{O}_{3}, \mathrm{Fe}_{2} \mathrm{O}_{3}$ ve diğer bileşenleri bünyesinde barındıran küllerdir. Kalsiyum oksit $(\mathrm{CaO})$ oranı $\% 10$ düzeyinden daha düşük, reaktif silis miktarı ise $\% 25$ düzeyinden fazladır. V sınıfında bulunan uçucu küller, genellikle puzolanik niteliklere sahip küresel ve tanecikli yapıdan meydana gelmektedir. TS EN 197-1'e bakıldığında $\mathrm{W}$ olarak sınıflandırılan uçucu küller, $\mathrm{SiO}_{2}, \mathrm{Al}_{2} \mathrm{O}_{3}, \mathrm{Fe}_{2} \mathrm{O}_{3}$ ve diğer bileşenleri bünyesinde barındıran küllerdir. Söz konusu küllerde kalsiyum oksit $(\mathrm{CaO})$ oranı $\% 10$ düzeyinden yüksek, reaktif silis miktarı ise $\% 25$ düzeyinden fazladır. Bu küller ise hidrolik ve puzolanik özellikler taşıyan küresel taneciklerden oluşmaktadır $[9,10]$.

\section{Sürdürülebilir Yöntem Olarak Betonda Puzolan Kullanımı}

Uçucu küller genellikle beton üretimi için katkı veya ikame malzemesi olması amacı ile kullanılmaktadır. Uçucu kül katkısı kullanılarak elde edilen çimento harcının fiziksel ve mekanik niteliklerinde olumlu sonuçlar sağlanabilmektedir. Uçucu külün kimyasal bileşimi, tanecik özellikleri ve puzolanik özelliği betonun fiziksel ve mekanik özelliklerini etkileyen önemli unsurlardır

Puzolanik özellik gösteren uçucu küller, kalsiyum hidroksit ile karıştırılarak su ile birleștirildiğinde, C-S-H (kalsiyum-silikathidrat) oluştururlar bu sayede bağlayıcılık özelliği kazanırlar. Çimento ile birlikte kullanıldıklarında betonun bağlayıcıllğına katkı sağlanabilir. Böylece betonun basınç ve aşınma dayanımında artı̧̧lar elde edilebilir

Beton bileşenlerinden çimento ile suyun tepkimesi sonucu kimyasal bir reaksiyon (hidratasyon) meydana gelir. Bu kimyasal reaksiyon süresince 1 sı (hidratasyon 1S1s1) açı̆̆a çıkar. Uçucu kül katkılı betonun hidratasyon 1sısı düşüktür dolayısı ile termik rötre ve çatlamalar önlenebilinir. Böylece betonun çevresel ve kimyasal etkilere karşı dayanıklılığı olumlu yönde geliştirilmiş olur. Resim 3 ve 4 'te portland çimentolu beton ve uçucu kül katkılı betonda oluşan rötre çatlakları gösterilmektedir.

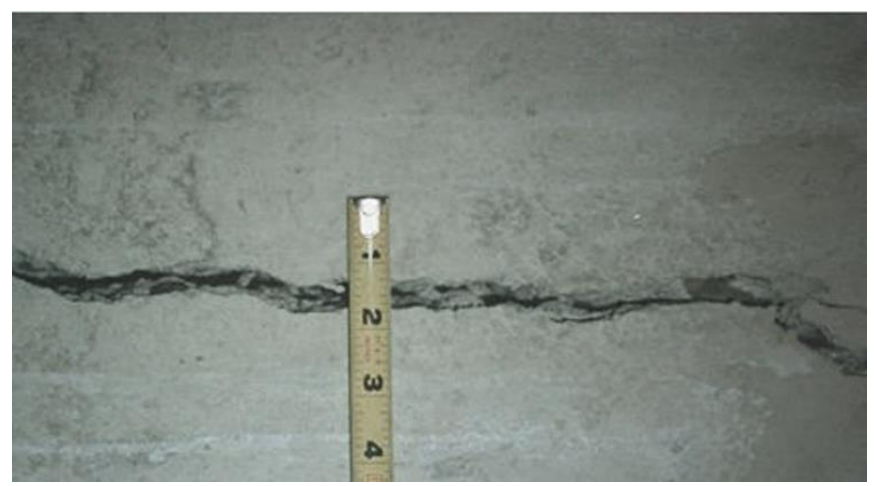

Resim 3. Portland çimentolu betonda rötre çatlă̆ı [11] 


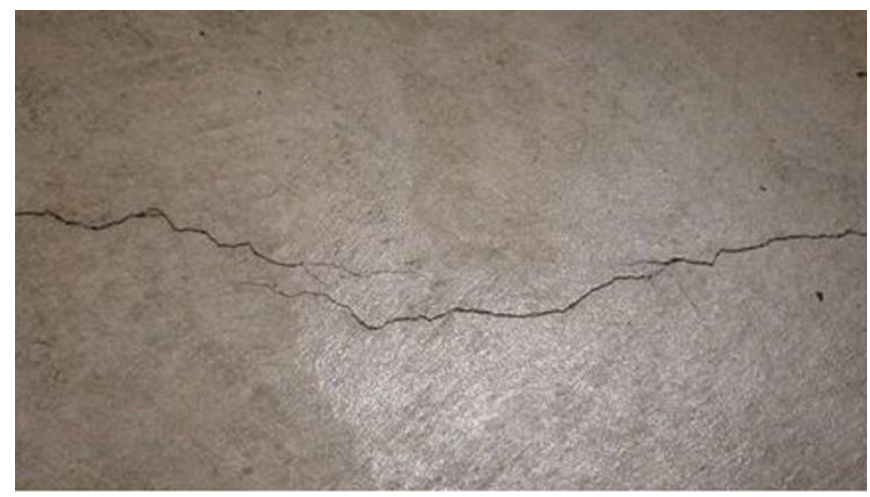

Resim 4. Uçucu kül katkılı betonda rötre çatlă̆̆ [11]

Uçucu küle ait tanecikler, küre şekline sahip, içyapısı boşluğa sahip olmayan veya tamamen senosfer yapıda boşluklu, plerosfer içerikli büyük küre tarafından gruplanan ufak kürecikler topluluğunun oluşturduğu özel bir yapıdadır. Bu yapıların dış yüzeyleri oldukça girintili çıkıntılı ve kristalizedir. [12]. Söz konusu küllerin camsı, küresel tanecikli yapıya sahip olması betona önemli katkılar sağlamaktadır. Uçucu külü oluşturan taneciklerin çapının küçük olmasından dolayı tanecikler arası boşluklar azdır. Böylece beton içindeki mikro gözenekler azaldıkça kılcal su geçirimliliği de azalmış olmaktadır. Beton dış etkilere daha dayanıklı hale gelir ve donatı korozyonu önlenebilir. Uçucu küller, yüzeyi düzgün küresel tanecikli yapıya sahip olmalarından dolayı su gereksinimi azdır. Düşük su/çimento bileşimi oranları ile istenilen düzeyde çalışma kolaylığına sahip ve yüksek kalitede beton üretimi sağlanabilir. Beton bileşimi içerisindeki su miktarının azalması ile su kaynaklarının tüketilmesi de engellenebilmiş olacaktır.

Uçucu küllerin birim ağırlığı, portland çimentosuna göre daha azdır. Betonda portland çimentosu yerine uçucu külün kullanılması betonun birim ağırlığını azaltır. Betonun birim ağırlığının azalması, toplam yapı ağırlığının hafiflemesini sağlar. Yapı ağırlığı ile orantılı olarak hesaplanan deprem yükleri azalacağından daha hafif, ve dayanıklı bir strüktüre sahip yapılar üretmek mümkün olabilecektir

Yapıda yangın yaşanması durumunda, yüksek sıcaklık etkisi ile beton malzemede çatlamalar ve parça ayrılmaları meydana gelebilir. Bu durumda betonarme strüktürün kesitinde azalmalar ve ağır hasarlar oluşabilir. Bu bağlamda 1sı iletim katsayısı düşük olan uçucu küllerin beton karışımındaki oranının arttırılması ile çimento harcının yüksek sıcaklıktan daha az zarar görmesi sağlanabilir ve betonun yüksek sıcaklık karşısında göstereceği dayanım arttırılabilir.

Uçucu küllerin doğaya salınmadan toplanabilmesi ve betonda kullanılabilmesi durumunda, betona kazandıracağı teknik özelliklerin yanı sıra doğaya salındığında oluşturacağı muhtemel çevre sorunlarının da önüne geçilmiş olunabilinir. Fosil yakıtla çalışan termik santrallerin en büyük çevresel etkileri atmosfere saldıkları uçucu küllerdir. Küllerin depolanması sırasında içlerinde bulunan gazların bir kısmının atmosfere yükselmesiyle asit yağmurları oluşmaktadır. Bunun sonucunda bitki örtüsü zarar görmekte ve insan sağlı̆̆1 olumsuz etkilenmektedir.

Uçucu külün çimento ile yer değiştirmesi, çimento üretiminde ortaya çıkan karbondioksit $\left(\mathrm{CO}_{2}\right)$ ve sera gazlarının salınımını azaltacak ve uçucu külün depolanması sorununu ortadan kaldıracaktır. Böylece doğa tahribatının önüne geçilmesi ve ekolojik dengenin korunması sağlanabilecektir. Ayrıca çimento üretiminde kullanılan enerji azalacağından bu üretim esnasında oluşan karbon emisyonu azaltılmış olacaktır. Enerji girdisi başlığı üzerinden sağlanmış olunacak tasarruf, toplam beton üretim maliyeti üzerinde birim fiyat düşüşünü sağlayabilecektir.

\section{Sürdürülebilir Puzolanik Malzemenin Kullanım Alanları}

Puzolan katkılı betonlar, istinat duvarları, su tankları, barajlar, köprüler, otoyollar, tuğla üretimi, hafif agrega üretimi, gazbeton üretimi, enjeksiyon betonları, zemin stabilizasyonu gibi bir çok alanda kullanılabilmektedir. Resim 5 'te puzolan katkılı tuğla bloklar görülmektedir.

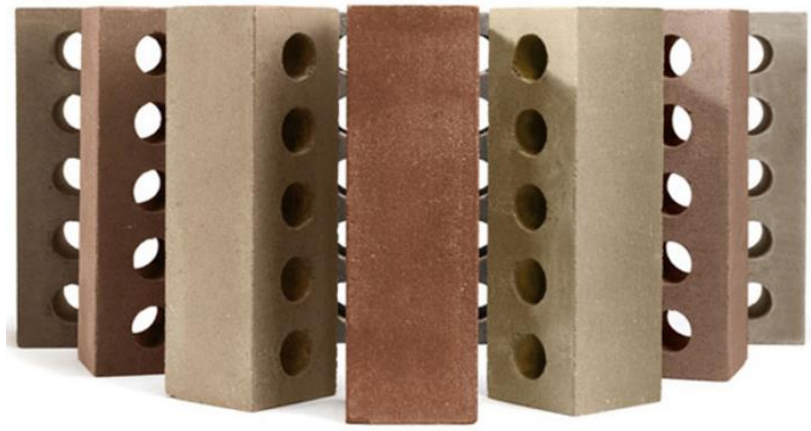

Resim 5. Puzolan katkılı tuğla bloklar [13] 
Uçucu küller, ilk kez 1930 yılında ABD'de kömür bazlı termik santrallerden elde edilmeye ve kullanılmaya başlanmıştır. 1930 yılından sonra uçucu külün kullanımı için bilim adamları araştırma faaliyetlerine başlamışlardır. R.E. Davis ve arkadaşları, 1937 yılında Kaliforniya Üniversitesi bünyesinde gerçekleştirdikleri uçucu külün beton içerisinde kullanımı araştırmalarını ve detaylarını yayınlamışlardır. Uçucu kül katkılı betonların en yaygın olarak kullanıldığı ülkelerin başında ise Hindistan, Çin ve ABD gelmektedir.

Resim 6'da 1931 yılında ABD'de uçucu külün kullanıldığı ilk proje olan Hoover Barajı görülmektedir. Sadece uçucu kül katkı1l beton kullanılarak yapılan ilk endüstriyel yapı ise 1948 yılında ABD'de yapılan Hungry Horse Barajı'dır. Resim 7'de ise 2013 yılında sadece uçucu kül katkılı betonun kullanıldığı ilk bina olan Avustralya'daki Queensland Üniversitesi'nin Küresel Değişim Enstitüsü görülmektedir.

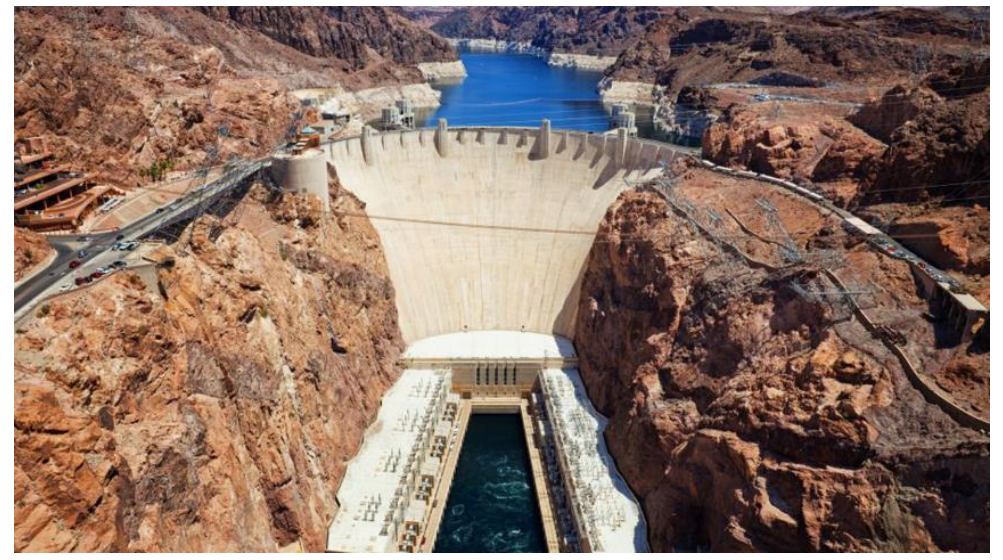

Resim 6. Hoover Barajl, ABD, 1931 [14]

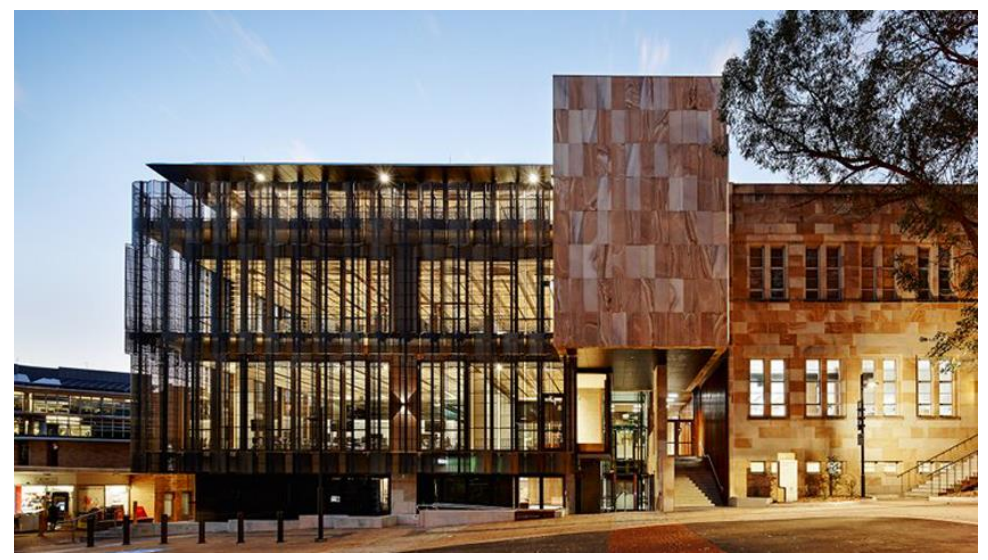

Resim 7. Queensland Üniversitesi, Küresel Değişim Enstitüsü, Avustralya, 2013 [15]

Uçucu kül katkılı betonun basınç ve aşınma dayanımı, kuvvetli geçirimsizlik özellikleri yüksektir. Dolayısıyla köprü ve baraj gibi yapılarda kullanımı oldukça elverişlidir. 1995 yılında yapılan Fransa'daki Puylaurent Barajı, 1998 yılında yapılan Danimarka'daki Great Bell East Köprüsü ve 2009 yılında yapılan Hindistan'daki Bandra Worli Köprüsü buna verilebilecek bazı örneklerdir.

Uçucu külün, betonun mekanik ve fiziksel özelliklerinde iyileşmeler sağlaması, yüksek sıcaklığa dayanımını artırması, hafifliğinin yanında mukavemetli oluşu çok katlı yapılarda kullanımını arttırmıştır. 1982 yılında yapılan İspanya'daki Picasso Gökdeleni, 1994 yılında yapılan Almanya'daki Kastor ve Pollux Gökdelenleri, 1998 yılında yapılan Malezya’daki Petronas İkiz Kuleleri ve 2010 yılında yapılan Dubai'deki Burj Khalifa uçucu kül katkılı beton kullanılmış yapılardır. 1955 yılında yapılan ABD'deki Prudential Finans Binası, 1988 yılında yapılan İskoçya'daki Tornes Nükleer Enerji Santrali, 2009 yılında yapılan ABD'deki Berkeley Sutardja Dai Hall uçucu kül katkılı betonun kullanıldığı diğer yapılar arasındadır.

Türkiye'de ise bu alandaki ilk çalışmalar 1964 yılında DSİ (Devlet Su İşleri Müdürlüğü) tarafından yapıllmıştır. 1968 yılında TSE (Türk Standartları Enstitüsü) tarafindan uçucu kül ile ilgili standartlar (TS EN-197, TS EN-450, TS EN-639, TS EN-640) yayınlanmıştır. Ülkemizde yılda ortalama 45 milyon ton düzeylerinde kömür yakılmaktadır. Buna bağlı olarak 15 milyon ton düzeyinde uçucu kül açığa çıkmaktadır [5]. TÇMB (Türkiye Çimento Müstahsilleri Birliği) ve EÜAŞ (Elektrik Üretim Anonim Şirketi) işbirliği ile Türkiye'de bulunan 11 termik santralden uçucu küller temin edilmiştir. Elektrofiltrelerden temin edilen uçucu küller içerisinde barındırdığı $\mathrm{CaO}$ yüzdesi ve $\mathrm{SiO}_{2}+\mathrm{Al}_{2} \mathrm{O}_{3}+\mathrm{Fe}_{2} \mathrm{O}_{3}$ toplam yüzdesi bakımından incelenmiş, ASTM-C 618 ve TS EN 197-1'e göre uygunlukları değerlendirilmiştir. Tablo 2'de Türkiye'deki termik santrallerden elde edilen uçucu küllerin analiz sonuçları gösterilmektedir. 
European Journal of Science and Technology

Tablo 2. Türkiye'deki termik santrallerin analiz sonuçları [16]

\begin{tabular}{|c|c|c|c|}
\hline \multicolumn{4}{|c|}{ Türkiye'deki Termik Santrallerin Analiz Sonuçları } \\
\hline Santral & $\mathrm{CaO}(\%)$ & $\mathrm{SiO}_{2}+\mathrm{Al}_{2} \mathrm{O}_{3}+\mathrm{Fe}_{2} \mathrm{O}_{3}(\%)$ & Sonuç \\
\hline Afşsin-Elbistan & 53,44 & 30,68 & Standartlara uygun değildir. \\
\hline Orhaneli & 9,48 & 80,73 & Standartlara uygundur. \\
\hline Çatalağzl & 1,46 & 89,75 & Standartlara uygundur. \\
\hline Seyitömer & 4,26 & 84,34 & Standartlara uygundur. \\
\hline Yatağan & 10,53 & 80,65 & Standartlara uygundur. \\
\hline Tunçbilek & 1,95 & 87,82 & Standartlara uygundur. \\
\hline Soma & 20,95 & 70,48 & Standartlara kısmen uygundur. \\
\hline Kangal & 31,91 & 53,37 & Standartlara kısmen uygundur. \\
\hline Yeniköy & 39,40 & 32,05 & Standartlara uygun değildir. \\
\hline Kemerköy & 38,49 & 43,76 & Standartlara uygun değildir. \\
\hline Çayırhan & 11,82 & 73,83 & Standartlara uygundur. \\
\hline
\end{tabular}

Türkiye'deki termik santrallerde yapılan araştırmalar ve çalışmalar sonucunda Seyitömer, Çatalağzı, Tunçbilek, Orhaneli, Yatağan ve Çayırhan santrallerinden elde edilen uçucu küllerin yapı malzemesi üretiminde uygun olduğu tespit edilmiştir. Buna rağmen yeterli düzeyde farkındalık oluşmaması, teknik ve ekonomik faydalarının göz ardı edilmesi, uçucu küllerin puzolanik özelliklerinden yararlanılarak onu sürdürülebilir güçlü bir yapı malzemesi olarak kullanmak yerine, bu külleri depolamak ve taşıdığı potansiyeli kullanmamak tercih edilmiştir.

Ülkemizde istisnai olsa da ilk uçucu kül katkılı beton uygulaması 1967 yllında yapımına başlanan Eskişehir'deki Gökçekaya Barajı'dır. Aynı yıl yapımına başlanan Porsuk Barajı'nın yapımında da uçucu kül kullanılmıştır. Barajların yapımında kullanılan beton karışımı, Tunçbilek Termik Santrali'nden elde edilen uçucu küllerin çimento ile karıştırılmasıyla elde edilmiştir. Resim 8'de Eskişehir'deki Gökçekaya Barajı gösterilmektedir.

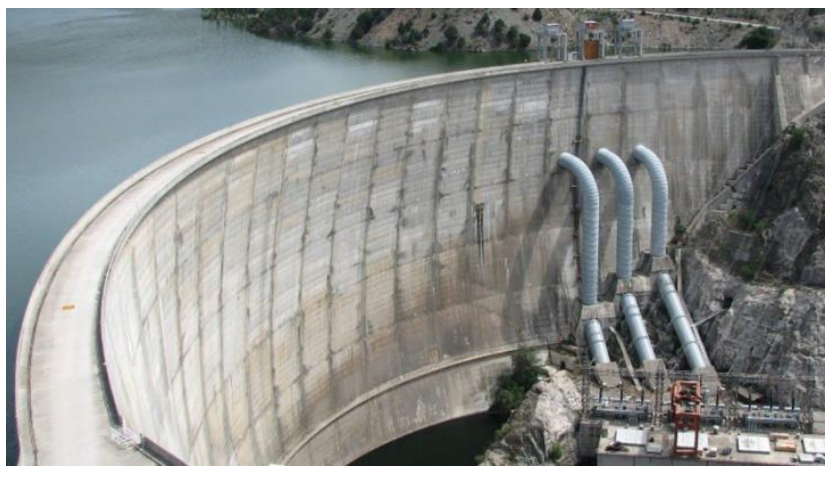

Resim 8. Gökçekaya Barajı, Eskişehir, 1967 [17]

\section{Sonuç}

Günümüzde sürdürülebilir tasarımın ve çevre dostu malzemelerin kullanımının yaygın hale getirilmesi amaçlanmaktadır. Puzolanik özellik taşıyan uçucu kül katkılı beton çevre dostu, sürdürülebilir, yenilikçi ve ekonomik bir ürün olarak yapı teknolojisinde ülkemizde de yerini almalıdır. Beton üretiminde uçucu küllerin, fırın cürufu ve silis dumanının kullanımı sayesinde sürdürülebilir ve çevresel koşullara daha dayanıklı ürünler elde edilebilmesinin yanı sıra endüstriyel atıkların çevre için oluşturdukları tehdit düzeyi de azaltılmış oluna bilinecektir. Bu nedenle, uçucu kül katkılı beton kullanımının yaygınlaştırılması, sürdürülebilir mimarlık ve atıkların çevreye verdiği zarar etkisinin azaltılması bakımından önemli görülmektedir.

Puzolanik özellik taşıyan uçucu kül katkılı betonun mukavemeti, su geçirimsizliği, hidratasyon 1sısının düşüklüğü gibi parametreler açısından çimentoya göre daha iyi özellikler sergilediği tespit edilmiştir. Uçucu küllerin beton teknolojisinde kullanımı ile betonun çeşitli fiziksel, mekanik ve durabilite özelliklerinin iyileştirilmesi, betonun performansının arttırılması, düşük maliyet ile yüksek kalitede beton üretilmesi sağlanabilir. Ayrıca uçucu küllerin beton üretiminin yanında tuğla üretiminde, gazbeton üretiminde, zemin iyileştirme tekniklerinde ve su yapılarında kullanılması da mümkündür. Uçucu küllerin depolanması sırasında çevreye yaydıkları atık gaz ortadan kaldırılabilinir, depolama ve taşıma esnasında kullanılması gereken enerjiden de tasarruf elde edilebilinir. Uçucu külün çimento ile yer değiştirmesi, çimento üretiminde ortaya çıkan karbondioksit $\left(\mathrm{CO}_{2}\right)$ ve sera gazlarının salınımının azalmasıyla doğanın tahribatının ve çevre kirliliğinin bir ölçüde önüne geçilmiş olunabilinir.

Türkiye'de uçucu kül kullanımı oldukça azdır. Ülkemizde uçucu küllerin geri dönüşümünün ve kullanımının yaygınlaştırılması ile ülke ekonomisine katkıda bulunulabilinir. Çevreye salınması veya depolanması durumunda oluşabilecek problemlerin ortadan kaldırılması mümkündür. Sürdürülebilir ve güçlü bir malzeme olarak görülen uçucu küller, ülkemizde bulunan altı termik santral tarafından büyük oranda üretilmektedir. Günümüzde sürdürülebilir mimarlık bakış açısı ile bu üretimin teknik ve ekonomik potansiyeli yeniden ele alınmalı, çevreye duyarlı bir bakış açısı ile ülke ekonomisine kazandırılmalı ve yapılaşma endüstrisinin faydasina sunulmalıdır.

e-ISSN: 2148-2683 


\section{Kaynakça}

[1] https://minerals.usgs.gov/minerals/pubs/commodity/cement/ (erişim tarihi 05.12.2017).

[2] ALKAYA, D. "Uçucu Küllerin Zemin İyileştirilmesinde Kullanılmasının İncelenmesi”, Yapı Teknolojileri Elektronik Dergisi, 5, 61-72, 2005.

[3] SHEIKH, A., SAIFALI, S., AKHIL, R., LAKSHMIPATHI, S. "Construction Of A Building Using Fly Ash Concrete", International Journal of Civil Engineering and Technology, 4, 1809-1814, 2017.

[4] TOPÇU, İ. B. VE CANBAZ, M. "Uçucu Kül Kullanımının Betondaki Etkileri”, Osmangazi Üniversitesi Mühendislik ve Mimarlık Fakültesi Dergisi, 14, 11-24, 2001.

[5] GÜLER, E., GÜLER, G., İPEKOĞLU, Ü., MORDOĞAN, H. “Uçucu Küllerin Özellikleri ve Kullanım Alanları”, Türkiye 19. Uluslararası Madencilik Kongresi ve Fuarı, İzmir, Türkiye, 9-12 Haziran 2005.

[6] http://www.caer.uky.edu/kyasheducation/flyash.shtml (erişim tarihi 05.12.2017).

[7] http://matrixxco.net/other/fly-ash-concrete/ (erişim tarihi 05.12.2017).

[8] ASTM C-618. Standart Specification for Fly Ash and Raw or Calcined Natural Pozolan for Use as Mineral Admixturein Portland Cement Concrete, The American Society for Testing and Materials, Philadephia, 1985. http://www.astm.org (erişim tarihi 07.12.2017).

[9] TS EN 197-1 Genel Çimentolar - Bileşim, Özellikler ve Uygunluk Kriterleri, Türk Standartları Enstitüsü, Ankara, 2012.

[10] TS EN 450-1 Uçucu Kül - Betonda Kullanılan - Bölüm 1: Tarif, Özellikler ve Uygunluk Kriteri, Türk Standartları Enstitüsü, Ankara, 2013.

[11] http://conash.com/ (erişim tarihi 05.12.2017).

[12] YAZICI, H. “Termik Santral Atığı Yapay Alçı-Uçucu Kül-Taban Külü Esaslı Yapı Malzemesi Geliştirilmesi”, Dokuz Eylül Üniversitesi, Fen Bilimleri Enstitüsü, Doktora Tezi, İzmir, 2004.

[13] https://ecofriend.com/eco-friendly-bricks.html (erişim tarihi 08.12.2017).

[14] https://www.culturalist.com/l/wonders-of-the-world-239449 (erişim tarihi 10.12.2017).

[15] https://inhabitat.com/the-global-change-institute-operates-in-a-net-zero-carbon-neutral-research-center-in-brisbane/ (erişim tarihi 10.12.2017).

[16] TÜRKER, P., ERDOĞAN, B., KATNAŞ, F., YEĞíNOBALI, A. ” Türkiye'deki Uçucu Küllerin Sınıflandırılması ve Özellikleri”, Türkiye Çimento Müstahsilleri Birliği/AR-GE Enstitüsü, Temmuz 2009.

[17] http://www.btselektrik.com.tr/sayfa-euas_gokcekaya_hes_rejenerasyon-1127.html (erişim tarihi 12.12.2017).

[18] ARUNTAŞ, H. Y. "Uçucu Küllerin İnşaat Sektöründe Kullanım Potansiyeli”, Gazi Üniversitesi Mühendislik ve Mimarlık Dergisi, 21, 193-203, 2006.

[19]ATİŞ, C. D. "Uçucu Kül İçeren, Silindirle Sıkıştırılabilen Betonların Özellikleri”, Turkish Journal of Engineering and Environmental Sciences, 25, 503-515, 2001.

[20] ÇİL, İ. “Uçucu Küllerin Beton Yapımında Kullanımı”, 56. Türkiye Jeoloji Kurultayı, Ankara, 2003.

[21]DEMİR, İ. "Uçucu Külün Hafif Yapı Malzemesi Üretiminde Kullanılması", Yapı Teknolojileri Elektronik Dergisi, 1, 21-24, 2005.

[22] https://theconstructor.org/concrete/geopolymer-concrete-ecofriendly-construction-material/9430/ (erişim tarihi 5.12.2017).

[23] KAPTANOĞLU, Ş. "Gökçekaya Baraj Ve Hidroelektrik", Türkiye Mühendislik Haberleri Dergisi, 142, 1-5, 1967.

[24] KARATAY, T. "Eskişehir Porsuk Barajı Yükseltilmesi İnşaat Çalışmaları", İnşaat Mühendisleri Odası Türkiye İnşaat Mühendisliği 4. Teknik Kongresi, Ankara, 1968.

[25] SUBAŞI, S., İŞBİLİR, B., ERCAN, İ. "Uçucu Kül İkameli Çimento Numunelerinin Mekanik Özelliklerine Yüksek Sicaklığın Etkisi”, Politeknik Dergisi, 14, 141-148, 2011.

[26] WASTİ, Y. "Uçucu Küllerin Geoteknik Özellikleri ve Kullanım Olanakları”, İMO Teknik Dergi, 4, 177-188, 1990. 